\title{
Effect of Foliar Spraying with Gibberellic Acid on Fruit Cracking of Pomegranate (Punica granatum L.)
}

\author{
1*Dr. Rida DRAIE; ${ }^{2}$ Ali ABORAS \\ ${ }^{1}$ Faculty of Agricultural Engineering, University of Idleb, Syria \\ ${ }^{2}$ Postgraduate Student, MA, Faculty of Agricultural Engineering, University of Idleb, Syria \\ *Corresponding Author: ridadraie@ hotmail.com
}

\begin{abstract}
Fruit cracking is one of the most important obstacles that pomegranate cultivation suffers from, which inflicts great damage on the crop, sometimes reaching more than $60 \%$. The research was carried out in the 20182019 agricultural season in a field planted with pomegranate trees, with the aim of studying the effect of foliar spraying with gibberellic acid in reducing fruit cracking. The experiment was conducted according to a complete randomized block design. We had three treatments for concentrations of gibberellic acid $(0,100$, and $200 \mathrm{ppm}$ ) and four treatments for the number of spraying times $(0,1,2$, and 3 times). The results showed the superiority of all treatments of spraying with gibberellic acid over the control treatment in most of the studied traits (early flowering and ripening time, increasing the percentage of fruit-set, improving the quality of fruits, increasing productivity). Increasing the number of spraying with gibberellic acid reduced the percentage of fruit cracking, as it reached $73.96 \%$, $24.08 \%, 13.81 \%$, and $12.98 \%$ in treatments of $0,1,2$ and 3 spraying times respectively. The increase of the spraying concentration also achieved a significant reduction in the percentage of cracking fruits, which amounted to $18.28 \%$ and $13.75 \%$ in the treatments of concentrations $A$ and $B$, respectively.
\end{abstract}

Keywords: Punica granatum, Fruit-Cracking, Foliar Spraying, Gibberellic Acid, Concentration, Spraying Times.

\section{INTRODUCTION}

The pomegranate tree (Punica granatum L.), of the Punicaceae family, is native to Central Asian regions, and from there it moved to the countries of the world (Chandler, 1957; Levin, 1994). It is currently cultivated in many different geographical areas including the Mediterranean basin, Asia, the USA and India (Bankar and Prasad, 1992; Holland et al., 2009).

The fruit cracking is one of the most important physiological diseases affecting pomegranates (Malhotra et al., 1983). As the cracked fruits are not desirable to the consumer. In addition, the high percentage of this disorder in some varieties of pomegranate and in some years, leads to reluctance to reap the fruits. Where (Panwar et al., 1994; Singh, 1995) showed that when the fruits crack, they are susceptible to infection with bacteria and fungi, and thus lose their marketing value and may become unfit for human consumption, causing a very large economic loss for pomegranate farmers and marketers alike (Finkel and Holbrook, 2000; Schrader et al., 2002).

Furthermore, about $25-40 \%$ of the fruits crack at the time of ripeness (Singh et al., 2006; Bankar and Prasad, 1992). The crack rate varies between $10-70 \%$ depending on climatic conditions, which reduces production to $50 \%$, and this is harmful to the farmer (Anonymous, 1983).

The cause of pomegranate cracking is mainly due to genetic factors (variety), in addition to environmental factors, and various agricultural treatments (Saad et al., 1988; Prasad et al., 2003; Chandra et al., 2011; Khadivi-Khub, 2014). Abd and Rahman (2010) indicated that the fruit cracking is associated with high temperature, high transpiration rate, low humidity in the air and soil, and sharp fluctuations in temperature between day and night during fruit growth. The correlation of the fruit cracking with irregular irrigation and lack of nutrients has also been emphasized (Gharesheikhbayat, 2006; Khalil and Aly, 2013; Saeiet al., 2014; Galindo et al., 2014). The degree of cracking varies according to the growth stages of the fruit, so cracking is more pronounced in the stage of ripening (Hoda and Hoda, 2013; Shulman et al., 1984; Yazici and Kaynak, 2006).

An imbalance between auxins, gibberellins and cytokinins causes the fruit crackimg (Rai et al., 2002). Healthy fruits contain a higher level of gibberellin and a lower level of ABA, as the imbalance between them in the peel of the fruits causes the fruit cracking (Sharma and Dhillon, 2002).Yazici and Ozguven (2006) showed the existence of a physiological relationship to hormones such as ABA (abscisic acid), IAA (Indole Acetic Acid) and GA3 (Gibberellic acid) with the cracking of immature fruits before harvesting in some pomegranate varieties. 
Josanet al. (1998) indicated that treatment with GA3 and NAA (Naphthalene Acetic Acid) led to a decrease in the percentage of cracking in lemon fruits, and the content of ABA was high in the control that contained the highest percentage of cracked fruits. El-Sese (1988) found that spraying with GA3 gave great fruit weights, increased soluble solids percentage, significantly augmented total acidity percentage, and reduced cracking ratio compared to control. Al-Dulaimi(1999) found that when spraying Slimy acid pomegranate variety after $80 \%$ of the flowers had appeared and 30 and 60 days after the first spraying with GA3 at concentrations of $(0,125,250 \mathrm{ppm})$, the third concentration reduced the percentage of cracked fruits from $15.63 \%$ to 9.35\%.Also, Yilmaz and Ozguven (2009) showed the significant effect of GA3 in the percentage of cracked fruits, as it led to a decrease in the rate of juice in the fruits, reduced the internal pressure on the peel, and thus decreased the percentage of cracked fruits, the effect was greater when treated with pinolene accompanied to gibberellin.

\section{RESEARCH AIM}

Pomegranate is grown in Syria to a fair degree, and its cultivation is self-sufficient with the export of part of the production. However, pomegranate cultivation in Syria in general and northern Syria in particular is exposed to many problems that affect the quantity and quality of production, the most important of which is the problem of fruit cracking. The degree of sensitivity to this problem varies according to the variety. The French variety is considered one of the most important cultivars cultivated in northern Syria in terms of cultivated area and in terms of local demand for the fruits of this variety. However, due to the sensitivity of this variety to the problem of fruit cracking, the areas cultivated with it began to decrease and to move towards the cultivation of other crops. Accordingly, this research has been conducted to study the effect of spraying with gibberellic acid (different concentrations and different number of spraying times) to reduce the fruit cracking of the French variety with the aim of preserving this locally desired variety.

\section{MATERIALS AND METHODS}

\subsection{Research Location}

The research was carried out during the years 2018-2019 in a private orchard in the city of Sarmada in the Idlib governorate, which is about $40 \mathrm{~km}$ north of Idlib, where the city of Sarmada is located at a latitude $36^{\circ}$ north and a longitude $36^{\circ}$ east. It rises about 383 meters. The total precipitation during the research season was $693 \mathrm{~mm}$, and the precipitation was concentrated in the winter months. The average minimum temperatures for the coldest month were $2^{\circ} \mathrm{C}$ (January), and the average maximum temperatures for the warmest month were $35^{\circ} \mathrm{C}$ (July and August), and the relative humidity ranged between $90 \%$ (January) and 25\% (May).

\subsection{Plant Material}

The experiment was conducted on a French pomegranate variety of 10-year-old trees planted at a distance of $4 \times 4 \mathrm{~m}$. As this variety is characterized by large fruits that are spherical to flat, the peel is red, the color of the fruits is bloody red, the neck of the fruit is long, the leaf is elongated, the branches have thorns, and its fruits are subject to cracking.

\subsection{Experimental Design and treatments}

The experiment was executed in the 2018-2019 agricultural season in a field planted with French pomegranate trees at the age of 10 years and dimensions $4 \times 4 \mathrm{~m}$. The complete randomized block design was used.

The trial included three treatments for the concentrations of gibberellic acid and four treatments for the number of foliar spraying times with gibberellic acid, according to the following:

1. Gibberellic acid concentrations: 0, 100 ppm (A), and 200 ppm (B).

2. Number of foliar spraying times: $0,1,2$, and 3 times:

- Control without spraying.

- Foliar spraying once after the beginning of flowering (1/5/2019).

- Foliar spraying twice after the beginning of flowering (1/5/2019) and after the completion of the fruit set (1/6/2019).

- Foliar spraying three times after the beginning of flowering (1/5/2019), after the completion of the fruit contract (1/6/2019), and when the fruits start to color (1/7/2019).

Five replicates per treatment, with one tree (French pomegranate variety) per replicate, were adopted. Consequently, the number of pomegranate trees used in the experimentation $=3$ concentrations $\mathrm{x} 4$ foliar spraying times $\mathrm{x}$ 5 replicates $\times 1$ tree $=60$ trees.

\subsection{Measured Parameters}

The following measurements were taken:

\section{Flowering traits}

- Number of days until the starting of flowering.

- Number of total flowers.

- Number of hermaphrodite flowers.

- Ratio of hermaphroditic flowers (\%).

\section{Fruits-set and Yield characteristics}


ISSN (online): 2581-3048

- Ratio of fruit-set (\%).

- Number of days until the date of fruits ripening.

- Productivity kg/tree.

3. Physical properties of fruits

- Ratio of cracked fruits per tree (\%).

- Diameter of fruit $(\mathrm{cm})$.

- Weight of fruits $(\mathrm{kg})$.

- Weight of fruit peels (g).

- Internal tissue weight (g).

- Weight of seeds (g).

- Weight of juice $(\mathrm{g})$.

4. Fruit quality characteristics

- Ratio of juice (\%).

- Total Soluble Solids (T.S.S.\%).

- Acidity of juice (pH).

\subsection{Statistical analysis}

The results were analyzed by the statistical program (GenStat-12). The averages were compared by calculating the LSD at the level of significance $(5 \%)$.

\section{RESULTS AND DISCUSSION}

\subsection{Study of the fruit cracking in the French variety}

The percentage of cracked fruits of the French variety at the site of the experiment was $73.96 \%$. This high value indicates the high sensitivity of the French variety towards fruit cracking. This value is greater than what was mentioned in previous studies. Singh et al. (2017) stated that the crack rate ranges between $18-62 \%$, and Pant (1976) stated that this percentage generally varies according to the varieties, and in the early ripening varieties it is about $34 \%$, while it reaches $63 \%$ in late-ripening varieties. Regarding the cracking types observed on the fruits of the French pomegranate variety were longitudinal cracking, transversal cracking, and sun blight cracking.

The fruit cracking had a negative effect on the overall characteristics of the fruit, as the weight of the peel decreased from $63.39 \mathrm{~g}$ in the healthy fruits to $61.03 \mathrm{~g}$ in the cracked fruits, the internal tissue weight decreased from $62.45 \mathrm{~g}$ in the healthy fruits to $55.79 \mathrm{~g}$ in the cracked fruits. Similarly, there was a big difference between the weight of the seeds which were $145.25 \mathrm{~g}$ in healthy fruits and $126.76 \mathrm{~g}$ in cracked fruits. The total weight of juice also decreased from $74.92 \mathrm{~g}$ in healthy fruits to $65.04 \mathrm{~g}$ in cracked fruits. The decrease in the aforementioned traits is explained by the increase in water loss and evaporation in the cracked fruits compared to the healthy ones, which was reflected in all the physiological processes in the fruit and thus led to a decrease in the weight and thickness of the external peel and a decrease in the weight of the inner tissues, seeds and juice (Hepaksoyet al., 2001; Galindo et al., 2014; Singh et al., 2020).

As for the size and weight of the fruit, they were also clearly affected, as the diameter of the fruit decreased from $8.71 \mathrm{~cm}$ in healthy fruits to $7.94 \mathrm{~cm}$ in cracked fruits, and the weight of the fruit decreased from $271.09 \mathrm{~g}$ in healthy fruits to $243.58 \mathrm{~g}$ in cracked fruits. The decrease in the diameter and weight of the fruit explains that they are also affected by the water condition of the fruit on the one hand and are directly related to the characteristics of the weight and thickness of the outer peel and the weight of the inner tissues, seeds and juice on the other hand (Saeiet al., 2014).

Otherwise, the percentage of total soluble solids (T.S.S.) increased, due to the effect of cracking, from $15.38 \%$ in healthy fruits to $16.12 \%$ in cracked fruits. The acidity level also increased, and the $\mathrm{pH}$ reached 2.64 in healthy fruits and 2.53 in cracked fruits. The increase in acidity (lower $\mathrm{pH}$ value) is explained by the lower moisture content in fruits that cracked due to evaporation and dehydration compared to the non-cracked fruits, which retain their moisture more due to the closing and the impermeability of their outer peel (Y1lmaz and Ozguven, 2009; Hoda and Hoda 2013).

The fruit cracking had a very significant effect on reducing the productivity of the French variety, as the productivity per tree was $13.01 \mathrm{~kg}$, of which only $3.38 \mathrm{~kg}$ were non-cracked and 9.63 cracked fruits (equivalent to $74.02 \%$ of cracked fruits). The high weight of cracked fruits indicates the great degree of damage that results from the cracking, and negatively affects the characteristics of the fruits and the economic and marketing value of these fruits. ElSayed et al. (2014) stated that the percentage of economic damage resulting from the fruit cracking reaches more than 50\%, while Pal et al. (2017) stated that the economic loss resulting from fruit cracking ranges between $10-40 \%$ on average, and sometimes it reaches $70 \%$.

\subsection{Effect of spraying concentration with gibberellin on the studied characteristics}

Table 1: Effect of spraying concentration with gibberellin on the studied characteristics

\begin{tabular}{|l|c|c|c|c|}
\hline Trait & $\mathbf{0}$ & $\mathbf{1 0 0}$ & $\mathbf{2 0 0}$ & $\begin{array}{c}\text { LSD } \\
(5 \%)\end{array}$ \\
\hline Flowering & 52.00 & 50.50 & 49.00 & 0.11 \\
\hline Ripening & 151.00 & 146.50 & 143.54 & 0.12 \\
\hline Number of total flowers & 287.33 & 457.48 & 493.65 & 1.89 \\
\hline $\begin{array}{l}\text { Percentage of hermaphrodite } \\
\text { flowers }\end{array}$ & 25.75 & 40.69 & 41.32 & 0.43 \\
\hline Percentage of fruit-set & 21.62 & 39.57 & 43.61 & 1.1 \\
\hline Diameter of fruit (cm) & 8.32 & 11.73 & 12.29 & 0.14 \\
\hline Weight of fruits (g) & 256.12 & 395.94 & 432.83 & 1.33 \\
\hline
\end{tabular}




\begin{tabular}{|l|c|c|c|c|}
\hline Weight of fruit peel (g) & 60.99 & 91.33 & 96.38 & 0.58 \\
\hline Internal tissues weight (g) & 59.12 & 79.56 & 89.11 & 0.84 \\
\hline Weight of seeds (g) & 136.01 & 225.05 & 247.34 & 1.26 \\
\hline Ratio of juice (\%) & 27.32 & 35.16 & 38.86 & 0.19 \\
\hline Acidity of juice (pH) & 2.98 & 3.39 & 3.51 & 0.03 \\
\hline $\begin{array}{l}\text { Total Soluble Solids } \\
\text { (T.S.S.\%) }\end{array}$ & 15.22 & 15.77 & 16.78 & 0.17 \\
\hline Productivity/tree (kg) & 11.36 & 18.22 & 20.36 & 1.2 \\
\hline
\end{tabular}

Table (1) shows that all the concentrations of foliar spraying with gibberellin exceeded the control in the number of days required to reach flowering (the value in the control was 52.00 days). The treatment of concentration B $(200 \mathrm{mg} / \mathrm{L})$ by 49.00 days outperformed the treatment of concentration $\mathrm{A}$ $(100 \mathrm{mg} / \mathrm{L})$ by 50.50 days. The foliar spraying concentrations outperformed the control in reaching the ripeness of the fruits, as the control needed 151 days, and the increase in the used concentration led to significant differences between the spraying treatments themselves, as the treatment of concentration B $(200 \mathrm{mg} / \mathrm{L})$ by 145.50 days outperformed the treatment of concentration A (100 mg/L) by 143.54 days.

The total number of flowers in the control reached 287.33; the percentage of hermaphrodite flowers was $25.75 \%$. The treatment of concentration A achieved a significant difference over the control with 457.48 flowers, which was also superior to the percentage of hermaphroditic flowers, which amounted to $40.69 \%$, while the treatment of concentration B achieved a significant difference above the treatment of concentration A in the total flowers (493.65 flowers), and in the percentage of hermaphrodite flowers also which amounted to $41.32 \%$, (Table 1). Our study agrees with (Shaheen, 1995) who showed that increasing the spraying concentration led to an increase in the percentage of hermaphroditic flowers in pomegranate.

Concerning the fruit-set, the foliar spraying with gibberellin and the increase in the spraying concentration have a positive effect on the fruit-set percentage, as the it was $21.62 \%$ in the control, $39.57 \%$ in the A concentration (100 $\mathrm{mg} / \mathrm{L})$, and $43.61 \%$ in the B concentration $(200 \mathrm{mg} / \mathrm{L})$, and the differences were significant between all treatments (Table 1). The effect of foliar spraying with gibberellin was significant on the weight and diameter of the pomegranate fruit, as the weight of the fruit in the control reached $256.12 \mathrm{~g}$ and the diameter was $8.32 \mathrm{~cm}$. The treatment of concentration A achieved a significant difference on the control, as the weight of the fruit was 395.94g and the diameter of the fruit was $11.73 \mathrm{~cm}$. Also, the treatment of concentration B achieved a significant difference above the treatment of concentration A, as the weight of the fruit was $432.83 \mathrm{~g}$ and the diameter of the fruit was $12.29 \mathrm{~cm}$, (Table 1).

The results of the statistical analysis according to Table (1) showed the significant effect of the concentrations used in the weight of the peel and the weight of the internal tissues of the fruit, as their weight in the control reached $60.99 \mathrm{~g}$ and $59.12 \mathrm{~g}$, respectively. The treatments of concentration A and B achieved a significant difference over the control. As the weight of the peel was $91.33 \mathrm{~g}$ and the internal tissue weight was $79.56 \mathrm{~g}$ in the treatment of concentration $\mathrm{A}$, and the weight of the peel was $96.38 \mathrm{~g}$ and the internal tissue weight was $89.11 \mathrm{~g}$ in the treatment of concentration B. Noting that the treatment of concentration $B$ is superior to the treatment of concentration A with significant differences.

Moreover, the weight of the seeds was increased by the effect of foliar spraying with gibberellin, reaching 136.01g, $225.05 \mathrm{~g}$, and $247.34 \mathrm{~g}$ in the control, treatment of concentration A, and treatment of concentration B, respectively (Table 1).

As for the percentage of juice, all the concentrations of spraying with gibberellin outperformed the treatment of the control, in which the juice percentage was $27.32 \%$. The treatment of concentration B $(200 \mathrm{mg} / \mathrm{L})$ outperformed the treatment of concentration A $(100 \mathrm{mg} / \mathrm{L})$ with juice of $38.86 \%$ and $35.16 \%$, respectively, (Table 1).Our study coincides with Fayed (2010) who showed that increasing the spraying concentration of pomegranate trees (Manfalouty cultivar), from $700 \mathrm{mg} / \mathrm{L}$ to $1000 \mathrm{mg} / \mathrm{L}$, this led to a significant increase in the percentage of juice in the fruit, and all treatments were significantly superior above the control.

The acidity of the juice decreased (the $\mathrm{pH}$ increased) due to the effect of foliar spraying with gibberellin, where the $\mathrm{pH}$ value was 2.98 in the control, 3.39 in the treatment of concentration $A(100 \mathrm{mg} / \mathrm{L})$, and 3.51 in the treatment of concentration B $(200 \mathrm{mg} / \mathrm{L})$. The differences were significant between all treatments. The T.S.S. also increased due to the effect of foliar spraying with gibberellin, as its value in the control reached $15.22 \%$. All the treatments outperformed the control, as the T.S.S. in the treatment of concentration B had reached $16.78 \%$, and it outperformed the treatment of concentration A, which had $15.77 \%$ (Table 1).

Table (1) indicates the significant effect of spraying with gibberellin on the productivity of the French pomegranate variety, as the productivity of the control reached 11.36 $\mathrm{kg} / \mathrm{tree}$. The treatment of concentration A $(100 \mathrm{mg} / \mathrm{L})$ achieved a significant increase over the control and the productivity reached $18.22 \mathrm{~kg} /$ tree. The treatment of concentration B $(200 \mathrm{mg} / \mathrm{L})$ achieved a significant increase over the treatment of concentration A with a productivity of $20.36 \mathrm{~kg} /$ tree. The differences were significant between all treatments. Thus, the spraying treatments achieved an increase in productivity over the control by $160.39 \%$ and $179.23 \%$ in the treatments of concentration A and B, respectively. 
4.3 Effect of spraying times with gibberellin on the studied characteristics

Table 2: Effect of spraying times with gibberellin on the studied characteristics

\begin{tabular}{|l|c|c|c|c|c|}
\hline Trait & $\mathbf{0}$ & $\mathbf{1}$ & $\mathbf{2}$ & $\mathbf{3}$ & LSD $_{(\mathbf{5} \%)}$ \\
\hline Flowering & 52.00 & 51.00 & 50.22 & 49.00 & 0.13 \\
\hline Ripening & 151.00 & 148.20 & 146.65 & 145.78 & 0.15 \\
\hline Number of total flowers & 287.33 & 413.70 & 459.54 & 492.66 & 2.02 \\
\hline Percentage of hermaphrodite flowers & 25.75 & 39.85 & 40.44 & 41.26 & 0.50 \\
\hline Percentage of fruit-set & 21.62 & 39.51 & 40.96 & 42.30 & 1.04 \\
\hline Diameter of fruit (cm) & 8.32 & 11.63 & 11.81 & 12.14 & 0.11 \\
\hline Weight of fruits (g) & 256.12 & 361.99 & 396.43 & 429.03 & 1.58 \\
\hline Weight of fruit peel (g) & 60.99 & 89.70 & 91.78 & 94.23 & 0.67 \\
\hline Internal tissues weight (g) & 59.12 & 71.67 & 79.46 & 88.57 & 0.75 \\
\hline Weight of seeds (g) & 136.01 & 200.62 & 225.19 & 246.23 & 1.37 \\
\hline Ratio of juice (\%) & 27.32 & 36.18 & 37.90 & 39.00 & 0.24 \\
\hline Acidity of juice (pH) & 2.98 & 3.34 & 3.40 & 3.49 & 0.02 \\
\hline Total Soluble Solids (T.S.S.\%) & 15.22 & 15.68 & 16.19 & 16.78 & 0.19 \\
\hline Productivity/tree (kg) & 11.36 & 17.01 & 18.89 & 20.74 & 1.07 \\
\hline
\end{tabular}

Table (2) shows the superiority of all spraying treatments over the control in the number of days required to reach flowering (as the value in the control was 52.00 days). The increase in the number of spraying times also had a positive effect in this aspect, as the treatment of three times spraying needed to 49.00 days higher than the treatment of spraying twice with 50.22 days, which outperformed the treatment of spraying once by 51.00 days. Table (2) also shows the significant effect of spraying in reaching the stage of fruit ripeness, as all treatments exceeded the control treatment, which required 151 days. The increase in the number of spraying times led to significant differences between the treatments. As the treatment of three times spraying (145.78 days) outperformed the treatment of spraying twice (146.65 days), which outperformed the treatment of spraying once (148.20 days).

Also, the increase in the number of spraying with gibberellin had a significant effect in increasing the number of total flowers and the percentage of hermaphroditic flowers. The total number of flowers in the control reached 287.33, of which $25.75 \%$ were hermaphrodites. The treatment of spraying once achieved a significant superiority over the treatment of the control, and the total number of flowers in it was 413.70 , with a percentage of hermaphroditic $39.85 \%$. The treatment of spraying twice achieved a significant superiority over the treatment of spraying once, as the number total of flowers in it was 459.54, from which $40.44 \%$ were hermaphroditic. While the treatment of three times spraying outperformed all treatments, as the total number of flowers was 492.66 , from which $41.26 \%$ was a hermaphrodite (Table 2).
Spraying and increasing the number of spraying times have a clear significant effect on the percentage of fruit-set, as it ratio reached $21.62 \%, 39.51 \%, 40.96 \%$, and $42.30 \%$, in the control, the treatment of spraying once, the treatment of spraying twice, and in the treatment of the three times spraying respectively, as the differences were significant between all treatments (Table 2).

Spraying and increasing the number of spraying times have a significant effect on increasing the weight and diameter of the fruit, as the weight of the fruit in the control reached $256.12 \mathrm{~g}$ and the diameter reached $8.32 \mathrm{~cm}$. The treatment of spraying once made a significant difference above the control, and the weight of the fruit in it was $361.99 \mathrm{~g}$ and the diameter of the fruit was $11.63 \mathrm{~cm}$. Also, the treatment of spraying twice achieved a significant difference over the treatment of spraying once, as the weight of the fruit was $396.43 \mathrm{~g}$ and the diameter of the fruit was $11.81 \mathrm{~cm}$. The treatment of three times spraying achieved a significant difference above the treatment of spraying twice, as the weight of the fruit was $429.03 \mathrm{~g}$ and the diameter of the fruit was $12.14 \mathrm{~cm}$ (Table 2).

The results of the statistical analysis according to Table (2) showed the significant effect of increasing the number of spraying times on the weight of the peel and the weight of the internal tissues of the fruit,as their weight in control reached $60.99 \mathrm{~g}$ and $59.12 \mathrm{~g}$, respectively. All the foliar spraying treatments achieved a significant superiority over the control treatment, as the weight of the peel was $94.23 \mathrm{~g}$ and the internal tissue weight was $88.57 \mathrm{~g}$ in the treatment of three times spraying. While, in the treatment of spraying twice, the weight of the fruit peel was $91.78 \mathrm{~g}$ and the weight of the internal tissues was $79.46 \mathrm{~g}$. As for the treatment of spraying once, the weight of the peel was $89.70 \mathrm{~g}$ and the weight of the 
internal tissues was $71.67 \mathrm{~g}$. The differences were significant between all treatments.

Table (2) shows the significant positive effect of spraying and of increasing the number of spraying times in increasing the weight of seeds, compared to the control in which the seed weight reached $136.01 \mathrm{~g}$. The treatment of spraying once outperformed the control, and the seed weight was 200.62g.The treatment of spraying twice also achieved a significant increase over the treatment of spraying once, and the seed weight was $225.19 \mathrm{~g}$. The treatment of three times spraying achieved a significant increase over the treatment of spraying twice and outperformed all treatments, as the seed weight was $246.23 \mathrm{~g}$.

Table (2) also shows the significant effect of spraying and the increase in the number of spraying times in the ratio of juice, as this percentage in the treatments reached $27.32 \%$, $36.18 \%, 37.09 \%$, and $39.00 \%$ in of the control, the treatment of spraying once, the treatment of spraying twice, and the treatment of three times spraying, respectively. Additionally, the treatment of three times spraying outperformed all treatments, and the differences were significant between all of these treatments.

Foliar spraying with gibberellin decreased the acidity of the juice (an increase in the $\mathrm{pH}$ value), with a $\mathrm{pH}$ value of 2.98.The increase in the number of spraying times achieved significant differences in this characteristic between the spraying treatments themselves. The treatment of spraying once significantly exceeded the control, with a $\mathrm{pH}$ of 3.34. Also, the treatment of spraying twice outperformed the treatment of spraying once, with a $\mathrm{pH}$ of 3.40.The treatment three times spraying outperformed all treatments, with a $\mathrm{pH}$ value of 3.49 (Table 2).

The T.S.S. increased due to the effect of foliar spraying with gibberellin, as its value in the control reached $15.22 \%$. All the treatments were significantly superior to the control, as the T.S.S. in the treatment of three times spraying reached
$16.78 \%$. It was significantly superior to the treatment of spraying twice, in which the T.S.S. was $16.19 \%$, which significantly outperformed the treatment of spraying once, in which the T.S.S. was $15.68 \%$ (Table 2).

Table (2) indicates the significant effect of increasing the number of spraying with gibberellin on the productivity of the French pomegranate variety, as the productivity in the control reached $11.36 \mathrm{~kg} /$ tree. The treatment of spraying once achieved a significant increase over the control, and the productivity reached $17.01 \mathrm{~kg} /$ tree. The treatment of spraying twice achieved a significant superiority over the treatment of spraying once, with a productivity of $18.89 \mathrm{~kg} /$ tree. While the treatment of the three times spraying significantly outperformed all treatments, its productivity reached 20.74 $\mathrm{kg} /$ tree. Consequently, the spraying treatments achieved an increase in productivity over the control by $149.64 \%$, $166.29 \%$, and $182.57 \%$ in the treatments of spraying once, twice, and tree times, respectively.

Our results are consistent with several studies on the effect of gibberellin foliar spray in improving pomegranate yield. Where gibberellin stimulates the elongation of plant cells, and leads to overcoming the genetic dwarfism of the stem, and increases the production of lateral branches, especially flowering, which increases the number of flowers and fruits and thus leads to increased production, in addition, that the gibberellin has an important role in increasing the size of fruits (Davies, 1995).

4.4 Effect of interaction between the spraying concentrations and spraying times with gibberellin on the studied characteristics

The interaction between the concentrations of spraying with gibberellin (concentration $100 \mathrm{mg} / \mathrm{L}$, and the concentration $200 \mathrm{mg} / \mathrm{L}$ ) and the number of spraying times with gibberellin (spraying once, spraying twice, and spraying three times) had a clear significant effect on all the studied characteristics compared with the control (Table 3).

Table 3: Effect of interaction between the spraying concentrations and spraying times with gibberellin on the studied characteristics

\begin{tabular}{|c|c|c|c|c|c|c|c|c|c|}
\hline $\begin{array}{l}\text { Spraying } \\
\text { times }\end{array}$ & $\begin{array}{c}\text { Spraying } \\
\text { concentration }\end{array}$ & $\begin{array}{c}\text { fruit-set } \\
\text { (\%) }\end{array}$ & $\begin{array}{c}\text { Peel } \\
\text { weight } \\
\text { (g) }\end{array}$ & $\begin{array}{c}\text { Fruit } \\
\text { weight } \\
\text { (g) }\end{array}$ & $\begin{array}{c}\text { Fruit } \\
\text { diameter } \\
\text { (cm) }\end{array}$ & $\begin{array}{l}\text { Juice } \\
\text { ratio } \\
(\%)\end{array}$ & $\underset{(\%)}{\text { T.S.S. }}$ & $\begin{array}{c}\text { Juice } \\
\text { pH }\end{array}$ & $\begin{array}{c}\text { Yield } \\
\text { (kg/tree) }\end{array}$ \\
\hline \multicolumn{2}{|c|}{ Control } & 21.63 & 60.99 & 257.32 & 8.32 & 27.17 & 15.22 & 2.58 & 6.51 \\
\hline \multirow{2}{*}{1} & 100 ppm & 38.41 & 89.70 & 370.21 & 11.56 & 34.93 & 15.21 & 3.34 & 16.35 \\
\hline & $200 \mathrm{ppm}$ & 41.79 & 93.70 & 397.53 & 11.97 & 38.04 & 16.12 & 3.40 & 18.32 \\
\hline \multirow{2}{*}{2} & $100 \mathrm{ppm}$ & 39.65 & 91.15 & 396.19 & 11.70 & 36.20 & 15.73 & 3.39 & 18.76 \\
\hline & $200 \mathrm{ppm}$ & 43.78 & 96.32 & 410.47 & 12.21 & 39.45 & 16.77 & 3.49 & 19.88 \\
\hline \multirow{2}{*}{3} & 100 ppm & 40.64 & 93.17 & 410.49 & 11.92 & 37.59 & 16.38 & 3.44 & 19.53 \\
\hline & $200 \mathrm{ppm}$ & 45.25 & 99.14 & 421.51 & 12.68 & 40.82 & 17.37 & 3.63 & 22.88 \\
\hline \multicolumn{2}{|c|}{ L.S.D. ${ }_{(5 \%)}$} & 2.08 & 1.33 & 3.86 & 0.22 & 0.48 & 0.38 & 0.04 & 1.10 \\
\hline
\end{tabular}


The reaction binary of concentration $\mathrm{B}$ and three times spraying outperformed the rest of all interactions, in the characteristics of the fruit-set ratio $45.25 \%$, the weight of the fruit peel $99.14 \mathrm{~g}$, the weight of the fruit $421.51 \mathrm{~g}$, the diameter of the fruit $12.68 \mathrm{~cm}$, the proportion of juice $40.82 \%$, the T.S.S. $17.37 \%$, the $\mathrm{pH} 3.63$, and the yield per tree 22.88 $\mathrm{kg} /$ tree. Then came the binaries of concentration B with spraying twice, concentration $\mathrm{B}$ with spraying once, concentration A with three times spraying, concentration A with spraying twice, then finally, concentration A with spraying once, respectively, in most of the studied characteristics. These results show a larger effect of the spraying concentration with gibberellin compared with the effect of the number of spraying times with gibberellin, as doubling the spraying concentration achieved greater effectiveness and led to the improvement of the studied characteristics compared to the increase in the number of spraying times.

\subsection{Effect of spraying with gibberellin on the fruit cracking of French pomegranate variety}

Foliar spraying with gibberellin resulted in a significant decrease in fruit cracking percentage compared to the control (Fig. 1). The percentage of cracked fruits in the control reached $73.96 \%$, and the treatment of concentration A (100 $\mathrm{mg} / \mathrm{L}$ ) achieved a significant decrease compared to the control, as the percentage of cracked fruits in the control reached $18.28 \%$. Also, the treatment of concentration B $(200 \mathrm{mg} / \mathrm{L})$ achieved a significant decrease in the percentage of cracking compared to the treatment of concentration A, which amounted to $13.75 \%$.

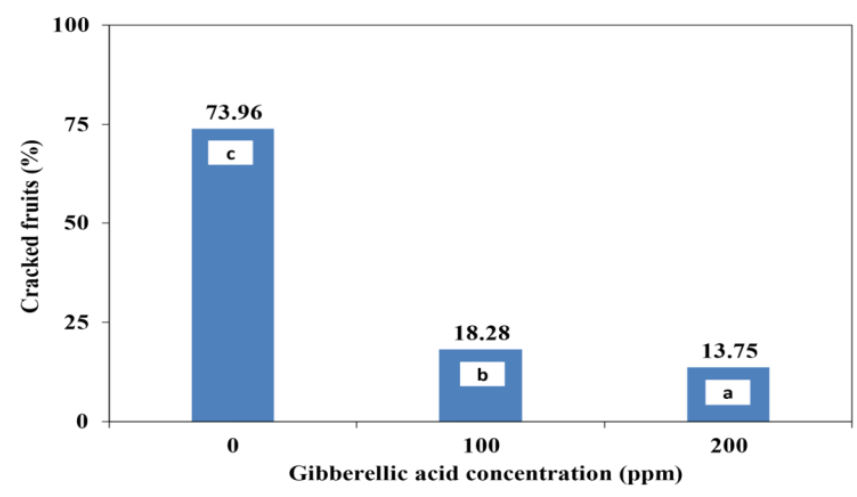

Figure 1: Effect of spraying concentration with gibberellin on the fruit cracking $\left(\operatorname{LSD}_{(5 \%)}=\mathbf{0 , 3 3}\right)$

Spraying and increasing the number of spraying times have a significant effect on reducing the percentage of cracked fruits compared to the control. The treatment of spraying once achieved a significant decrease over the control, and the percentage of cracked fruits reached $24.08 \%$. Also, the treatment of spraying twice treatment also achieved a significant decrease in the cracking rate, which reached
$13.81 \%$ compared to the treatment of spraying once. The largest decrease in the percentage of cracked fruits was in the treatment of the three times spraying, as the percentage of cracked fruits in this treatment was $12.98 \%$, which significantly outperformed all treatments (Fig. 2).

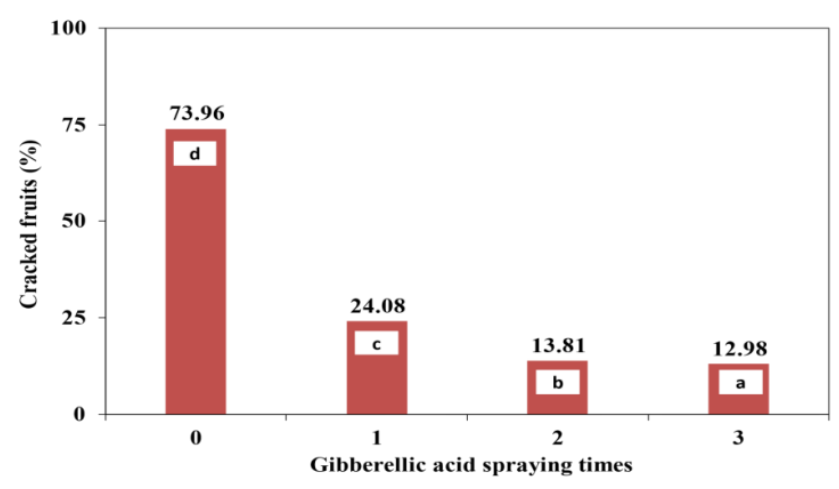

Figure 2: Effect of spraying times with gibberellin on the fruit cracking $\left(\mathbf{L S D}_{(\mathbf{5} \%)}=\mathbf{0 , 2 3}\right)$

As for the interaction between the concentrations of spraying with gibberellin $(0,100$, and $200 \mathrm{mg} / \mathrm{L})$ and the number of spraying times with gibberellin $(0,1,2$, and 3 times), the effect was significant in reducing the percentage of fruit cracking of the French pomegranate variety compared to the control, in which the rate of cracking is $73.96 \%$, (Fig. 3). The binary reaction of concentration $\mathrm{B}$ and the three times spraying outperformed the remaining reactions by $17.82 \%$, followed by the binary interaction of concentration B with the spraying twice by $20.52 \%$. Then followed by the binary interaction of concentration A with the three times spraying, at a rate of $27.39 \%$, followed by the binary reaction of concentration A with the spraying twice at a ratio of 33.32 , then the binary reaction of concentration $\mathrm{B}$ with spraying once at a rate of $44.19 \%$, finally the binary interaction of concentration A with spraying once at $48.96 \%$. Consequently, the differences were significant between all these interactions.

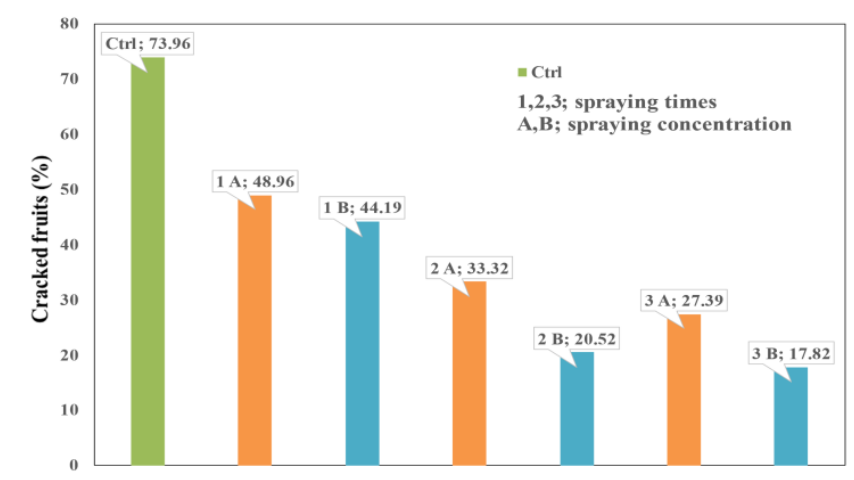

Figure 3: Effect of interaction between the spraying concentration and spraying times with gibberellinon the fruit cracking $\left(\operatorname{LSD}_{(5 \%)}=0,7\right)$

Our results coincide with many studies that showed the importance of spraying with gibberellin in reducing the percentage of cracked pomegranate fruits and its negative 
effects. El-Sese, (1988) showed that the spraying with gibberellin decreased the percentage of cracking of pomegranate fruits compared to the control. In an experiment conducted by Al-Dulaimi (1999) when spraying pomegranate trees of the Slimy acid variety three times: the first after the appearance of $80 \%$ of flowers, the second and third 30 and 60 days (respectively) after the first spraying, the spray was done with gibberellin GA3 at concentrations $(0,125$, and $250 \mathrm{ppm})$, he found that the third concentration was found to reduce the percentage of split fruits from $15.63 \%$ to $9.35 \%$.

Also, Yilmaz and Ozguven (2009) showed the significant effect of gibberellic acid in reducing the percentage of cracked fruits, as it led to a decrease in the rate of fruit juice, reduced the internal pressure on the peel, so reducing the percentage of cracked fruits. The effect was greater when the fruit treated with Pinolene (Anti-Transpiration) escorted with the gibberellin.

\section{CONCLUSIONS}

1. All treatments of spraying with gibberellin outperformed the control treatment in most of the studied characteristics (early flowering and ripening time, increasing the ratio of fruit-set, improving the quality of fruits).

2. The increase in the number of spraying times with gibberellin had a significant positive effect in increasing the productivity compared to the control, as the augmentations was $149.74 \%, 166.29 \%$ and $182.57 \%$ in the treatment of spraying once, twice, and three times, respectively.

3. The increase in the spraying concentrations had a positive significant effect in improving the productivity correlated to the control, as the improvements was $160.39 \%$ and $179.23 \%$ in the treatments for the concentrations $\mathrm{A}$ and $\mathrm{B}$, respectively.

4. The increase in the number of spraying with gibberellin reduced the percentage of fruit cracking compared to the control, as the percentage of fruit cracking reached $24.08 \%, 13.81 \%, 12.98 \%$, in the treatment of spraying once, twice, and three times, respectively.

5. The increase in the spraying concentration with gibberellin led to a reduction in the percentage of fruit cracking compared to the control, as the percentage of fruit cracking was $18.28 \%$ and $13.75 \%$ in the treatments of concentration $\mathrm{A}$ and $\mathrm{B}$, respectively.

\section{REFERENCES}

[1] Abd I.E.; Rahman E.I. (2010). Physiological studies on cracking phenomena of pomegranate. J. AppI. Sci. Res. 6:669-703.
[2] Al-Dulaimi R.M.H. (1999). Factors affecting fruit cracking, yield characteristics, and susceptibility to pomegranate. Punica granatum L., a slimy acid variety. PhD thesis. University of Baghdad, College of Agriculture, Iraq.

[3] Anonymous A. (1983). Second National workshop. Arid zone fruit Research Technology. Dec. 10-13.

[4] Bankar G.J.; Prasad R.N. (1992). Performance of important pomegranate cultivars in arid region. Annals of arid Zone 31(3):181-183.

[5] Bhowmik D.; Gopinath H.; Pragati-Kumar B.; Duraivel S.; Aravind G.; Sampath-Kumar K.P. (2015). Medicinal Uses of Punica granatum and Its Health Benefits. 1(5):28-30.

[6] Chandler W.H. (1957). Deciduous Orchards. 3 rd. Edition by LEA \& Philadelphia, U.S.A, 34-39.

[7] Chandra R.; Suroshe S.; Sharma J.; Marathe R.A.; Meshram D.T. (2011). Pomegranate growing manual. NRS on pomegranate, Solapur. 1-58.

[8] Chaudhari B.B.; Suryawanshi K.K.; Shinde V.B. (2015). Health Benefits of Pomegranate. Indian Farmer 2(9):691-693

[9] Davies P.J. (1995) - Plant Hormones Physiology, Biochemistry and Molecular Biology. Dordrecht, The Netherlands: Kluwer Academic. 833p.

[10] El-Sayed O.M.; El-Gammal O.H.M.; Salama A.S.M. (2014). Effect of proline and tryptophan amino acids on yield and fruit quality of Manfalouty pomegranate variety. Scientia Hort. 169:1-5.

[11] El-Sese A.M. (1988). Effect of time of fruit setting on the quality of some pomegranate cultivarse. Assiut J.Agric.Sci. 19(3) 55-69 p.

[12] Fayed T.A. (2010). Effect of compost tea and some antioxidant applications on leaf chemical constituents, yield and fruit quality of pomegranate. World J. Agric. Sci., 6(4): 402-411.

[13] Finkel T.; Holbrook N.J. (2000). Oxidants, oxidative stress and the biology of ageing. Nature 408:239-247.

[14] Galindo A.; Rodriguez P.; Gollado-Gonzalez J.; Cruz Z.; Torrecillas E.; Ondono S.; Corell M.; Moriana A.; Torrecillas A. (2014). Rainfall intensifies fruit peel cracking in water stressed pomegranate trees. Agric. Meteorol. 194:29-35.

[15] Gharesheikhbayat R. (2006). Anatomical study of fruit cracking in pomegranate c.v. Malas-e-Torsh. PajoheshSazandegy 69:10-14.

[16] Hepaksoy S.; Aksoy U.; Can H.Z.; Uhj M.A. (2001). Determination of relationship between fruit cracking and some physiological responses, leaf characteristics and nutritional status of some pomegranate varieties. Faculty of Agri. Hort. Enge. Univer. 87-92. 
[17] Hoda A.K.; Hoda S.H.A. (2013). Cracking and fruit quality of pomegranate (Punica granatum L.) as affected by pre-harvest sprays of some growth regulators and mineral nutrients. J. Hortic. Sci. Ornamental plants 5:71-76.

[18] Holland D.; Hatib K.; Bar-Yaakov I. (2009). Pomegranate: Botany, horticulture, breeding. Hort. Rev. 35:127-191.

[19] Josan J.S.; Sandhu A.S.; Zora S. (1998). Effect of plant Growth Regulation sprays on the Endogenous Level of Phytohormones and splitting of Lemon fruit. Recent Hort. 4:19-21.

[20] Khadivi-Khub A. (2014). Physiological and genetic factors influencing fruit cracking. Acta physiol. Plant. 37:1-14.

[21] Khalil H.A.; Aly H.S. (2013). Cracking and fruit quality of Pomegranate (Punica granatum L.) as affected by pre-harvest sprays of some growth regulators and mineral nutrients. J. Hortic. Sci. Ornam plants 5:71-76.

[22] Levin G.M. (1994). Pomegranate (Punica Granatum) Plant Genetic Resourses in Turkmenistan. Plant Resources Newsletter, 97:31-36.

[23] Malhotra V.K.; Khajuria H.N.; Jawanda J.S. (1983). Studies on physio-chemical characteristics. 1physical characteristics. Punjab Hort. J. 23: 153-157.

[24] Morton J.E. (1987). Fruits of warm climates. Miami, Florida, 352-355.

[25] Pal R.K.; Singh N.V.; Maity A. (2017). Pomegranate fruit cracking in dryland farming curr. Sci. 112: 896897.

[26] Pant T. (1976). Fruit cracking in pomegranate (Punica granatum L.) in variety Judipuri. Udyanika, Hort. 48(2): 29-35.

[27] Panwar S.; Desair U.T.; Chouduhary S.M. (1994). Effect of pruning on physiological disorder in pomegranate. Annals of Arid Zone 33:83-84.

[28] Prasad R.N.; Bankar G.J.; Vashishtha B.B. (2003). Effect of drip irrigation on growth, yield and quality of pomegranate in arid region. Indian J. Hort. 60:140-142.

[29] Rai M.; Day P.; Nath V.; Das B. (2002). Litchi production technology. Horti. and Agroforestry Res. Prog., Ranchi 21p

[30] Saad F.A.; Shaheen M.A.; Tawfik H.A. (1988). Anatomical stydy cracking pomegranate fruit. Alexandria Journal of Agri. Research, 33(1):155166.

[31] Saei H.; Sharifanni M.M.; Dehghanic A.; Esmaeil S.; Vahid A. (2014). Description of biomechanical forces and physiology parameters of fruit cracking in pomegranate. Scientia Hortic. 178:224-230.
[32] Schrader L.; Zhang J.; Sun J. (2002). Environmental stresses that cause sunburn of apple. XXVI. International Horticultural congress \& Exhibition, Toronto 11:397-405.

[33] Shaheen S.A.A. (1995). Effect of foliar sprays of some nutrients on flowering and fruiting of olive trees. M.SC. Thesis. Fac. of Agric. Cairo unir, 122p.

[34] Sharma K.K.; Dhillon W.S. (2002). Evaluation of evergreen varieties of pomegranate under Punjab conditions. Agric. Sci. Digest. 22: 42-44.

[35] Shulman S.; Fainberstein L.; Lavee S. (1984). Pomegranate fruit development and maturation. $J$. Hortic. Sci. 59:265-282.

[36] Singh A.; Burman U.; Saxena A.; Meghwal P.R. (2017). Interactive effects of micronutrients, Kaolin and mulching under drip irrigation system in managing fruit cracking of pomegranate (Punicagranatum L.). ISHS, IV. Int. Symp., pomegranate and Minor Mediterranean Fruits, Elche, Valancia, Spain, 16-19.

[37] Singh A.; Shukla A.K.; Meghwal P.R. (2020). Fruit Cracking in Pomegranate: Extend, Cause, and Management - A Review. International Journal of fruit science. 1-20.

[38] Singh D.B.; Kingsly A.R.P.; Jain R.K. (2006). Controlling fruit cracking in pomegranate. Indian Hort. 51(1):14-32.

[39] Singh S.P. (1995). Pomegranate in commercial fruits. pp. kalyani publisher, Ludhiana: 225-233.

[40] Yazici K.; Kaynak L. (2006). Effect air temperature relative humidity solar radiation fruit surface temperatures sunburn damage pomegranate Punica granatum L. c.v. Hicaznar. Acta. Hort. 181-186.

[41] Yilmaz C.; Ozguven A.I. (2006). Hormone physiology pre-harvest fruit cracking pomegranate (Punica granatum L.) Verification Anne.Acta.Hort. 545-549.

[42] Yilmaz C.; Ozguven A.I. (2009). The effect of some plant nutrients gibberellic acid and pinolene treatments on the yield, fruit quality and cracking in pomegranate cation anne. Acta. Hort. 205-212. 
Citation of this Article:

Dr. Rida DRAIE; Ali ABORAS, "Effect of Foliar Spraying with Gibberellic Acid on Fruit Cracking of Pomegranate (Punica granatum L.)" Published in International Research Journal of Innovations in Engineering and Technology - IRJIET, Volume 5, Issue 2, pp 53-62, February 2021. Article DOI https://doi.org/10.47001/IRJIET/2021.502009 